\title{
Is socio-economic status associated with adverse birth outcomes in Poland?
}

\author{
Agnieszka Genowska, ${ }^{1, A-B, D-F \circledast}$, Justyna Fryc ${ }^{1, A, D-F \oplus}{ }^{\text {, Andrzej Szpak }}{ }^{2,3 C, E-F \oplus}$, Piotr Tyszko ${ }^{2, C, E-F \circledast ~}$ \\ ${ }^{1}$ Medical University, Bialystok, Poland \\ 2 Institute of Rural Health, Lublin, Poland \\ ${ }^{3}$ University of Economics and Innovation, Lublin Poland \\ A - Research concept and design, B - Collection and/or assembly of data, C - Data analysis and interpretation, \\ $D$ - Writing the article, E - Critical revision of the article, F - Final approval of article
}

Genowska A, Fryc J, Szpak A, Tyszko P. Is socio-economic status associated with adverse birth outcomes in Poland? Ann Agric Environ Med. 2019; 26(2): 369-374. doi: 10.26444/aaem/95215

\begin{abstract}
Introduction. Low birth weight (LBW) is an important indicator of the healthy of the population and reflects the living conditions, health and health behaviours of pregnant women.

Objective. To assess the relationship between Gross Enrollment Rate at the Tertiary Education Level, average salary, Gross Domestic Product per capita, unemployment, housing area, urbanization and low birth weight in Polish sub-regions.

Materials and method. An ecological study was undertaken using data on socio-economic and demographic features and LBW in 2005-2014. The units of observation were 66 Polish sub-regions according to the NUTS-3 classification. Two models were used to assess the influence of SES variables on LBW incidence rate in a 10-year study period. The first was the Poisson regression model adjusted for density of population, which was followed by the multivariable model using the GEE method of model parameters estimation.

Results. In Poland, significant slow changes in the LBW incidence rate were observed in 2005-2014 (AAPC $=-0.44 \% /$ year). In model 1, the increase in LBW was associated with an increase in unemployment (1.005) and decrease of average salary (0.987), GERTEL (0.990) and housing area (0.991). In model 2, an unfavorable association was detected between the density of population (1.068) and a still existing relationship with unemployment (1.004), average salary (0.990) and GERTEL (0.991). Conclusion. Protective factors for newborns' health were a higher level of education and income. The results indicate the need to take actions to reduce the risk factors of LBW among pregnant women living in densely populated areas.
\end{abstract}

Key words

low birth weight, newborns, health status, social inequalities in health, urbanization, education, salary, unemployment

\section{INTRODUCTION}

Low birth weight (LBW) is an important indicator of the healthy of the population, reflecting the health, health behaviours and living conditions of pregnant women [1]. LBW is defined as birth weight below 2,500 $\mathrm{g}$ of newborns born less than 37 weeks of gestational age and neonates with intrauterine growth retardation (IUGR) born at term [2]. Pregnancy is a particularly vulnerable period of human development, in which the occurrence of unfavourable events and processes determine the long-term health effects. Birth outcomes, including LBW and preterm birth (PTB), are associated with the emergence of inequities in health, manifested by an increased risk of various health problems $[3,4]$. Poor health at birth is a prognostic factor of survival, as confirmed by the estimates of EUROPERISTAT indicating that LBW and PTB account for approximately $75 \%$ of deaths in newborns and $60 \%$ of deaths in infants [5]. Adverse birth outcomes are also associated with respiratory distress syndrome, necrotizing enterocolitis and neurologic long-term morbidities (cerebral palsy, blindness, deafness, hydrocephaly). These problems generate significant costs for hospital care in intensive care units with specialized equipment to support and monitor vital functions. Among children born with LBW, the risk of neurodevelopmental

Address for correspondence: Agnieszka Genowska, Medical University, Bialystok Poland

e-mail: agnieszka.genowska@umb.edu.pl

Received: 19.04.2018; accepted: 18.09.2018; first published:05.11.2018 disorders is elevated throughout life, which may affect the results of the educational process. In adulthood, there is a greater risk of chronic diseases, such as diabetes, hypertension and heart disease $[4,6]$.

There are many reasons for LBW, among which the characteristics features of the mother are mentioned, i.e. age (under 20 or over the age of 40), comorbidities (hypertension, diabetes, infections) and nutrition deficiencies $[4,7]$. The exposure to severe or prolonged stress, which in many cases results in the use of stimulants, among others tobacco (active or passive), and alcohol may play a significant role [7-9]. These exposures often co-occur in women with low socioeconomic status (SES) who perform heavy physical work under unfavourable working conditions. Women with a lower level of education rarely use or delay gynecological and obstetric care. In addition, the structural factor, including the living environment, the level of economic development in the place of residence, as well as the redistribution of resources in society, can play a significant role [10-12]. It should be emphasized that the socio-economic factors contributing to the formation of LBW are mostly modifiable. From the perspective of public health, it is important to identify both individual and structural risk factors in order to reduce inequalities in the birth weight of newborns.

In 2014, in the European Union (EU) countries the average LBW value was 7.1\%, the lowest level observed in Northern European countries (Finland 4.2\%, Latvia 4.4\%, Lithuania $4.5 \%$, Estonia and Sweden $4.6 \%$ ), with an unfavorable situation mainly occurring in Southern European countries 
(Spain - 8.2\%, Romania - 8.3\%, Portugal - 8.7\%, Hungary $8.9 \%$, Greece $-9.0 \%$, and Bulgaria - 9.4\%) [13]. Considerable variation in the prevalence of LBW in the EU may be the result of a complex interaction between cultural factors, access to healthcare, labour market conditions and economic development, which are known to be clustered in space [5, 14]. In Poland, the percentage of LBW was slightly lower than the EU average and amounted to 5.8\% [13], but little is known to what extent the structural factors are related to LBW. Studies conducted by Polish researchers describe only the relationship between LBW and mothers' age, the sequence of deliveries, the way of completing pregnancy [15-17], smoking $[18,19]$, education, and time to register for the first visit [19-21]. Taking into account the knowledge about structural conditions and results of birth, one can expect a relationship between SES and LBW characteristics at the population level.

\section{OBJECTIVE}

The purpose of this study was to assess the relation between Gross Enrollment Rate at the Tertiary Education Level, average salary, Gross Domestic Product per capita, unemployment, housing area, urbanization and low birth weight in Polish sub-regions.

\section{MATERIALS AND METHOD}

The research material was data from the birth cards of 227,696 live births with LBW below 2,500 g from a total of 3,891,297 live births in Poland between 2005-2014. The analysis omitted 72 birth cards with missing information on birth weight. The study used information on the characteristics of SES, i.e. Gross Enrollment Rate at the Tertiary Education Level (GERTEL), average salary, Gross Domestic Product (GDP) per capita, unemployment rate and housing area. Information on the urbanization level of sub-regions, recognized as a social determinant of population health, was also used. In order to overcome the differences between sub-regions, the density of population rate was included as a standardizing factor. Information on LBW, SES and urbanization was obtained from Central Statistical Office.

An ecological study was undertaken using data on LBW and socio-economic and demographic features in 20052014. The units of observation were 66 Polish sub-regions - territorial units defined as the NUTS-3 classification (Nomenclature des Unités territoriales statistiques), which is the standard for the EU. This division is a geographical standard developed in the EU for identification of statistical territorial units [22].

The distribution of LBW, socio-economic characteristics and urbanization in 66 sub-regions of Poland was described by giving the mean, standard deviation, quartiles, minimum and the maximum values. These descriptive statistics were weighted for number of live births in each sub-region.

Initially, correlations between SES variables and LBW incidence for averaged data from 2005-2014 were assessed with Spearman's correlation coefficients. Subsequently, the influence of SES variables on LBW incidence was estimated in the 10 -year study period with the Poisson regression model. The Generalized Estimating Equations (GEE) model was applied because it allows the use of data with repeated measurements for the same statistical units (data from different years) [23]. The application of GEE allows for correct estimatation of the model parameters (compared to simple linear regression model). Ignoring these correlations may lead to overestimating standard errors and inflating Type II error. In the current study, the correlations for all variables between different years were very high (between 0.91-1.00). This fact implies the use of GEE model.

Two types of models were evaluated. First model included each of SES variables separately, the year of observation and density of population as an indicator of urbanization. Because the population density was significantly rightskewed, for statistical analyses logarithm at base 2 of the source variable was used. The second model included all SES variables, year of observation and density of population. To estimate goodness of fit of the described models, Corrected Quasi-Likelihood under Independence Model Criterion (QICC) was used. These values were computed using the full log quasi-likelihood function and presented in smallis-better form.

The results are presented as Incidence Rate Ratio (IRR) with $95 \%$ confidence intervals of LBW and p-values of corresponding Wald's tests.

All regression models included the year of observation. The impact of this variable was presented as Average Annual Percent Change (AAPC) of the LBW during the studied period (2005-2014). The AAPC of the LBW was also determined in each sub-region separately and presented graphically on a map.

All calculations were performed with IBM ${ }^{*}$ SPSS ${ }^{\circ}$ Statistics for Windows, Version 20.0-IBM Corp. Armonk, NY, USA. All statistical tests were considered significant if $\mathrm{p}$-value was below 0.05 .

\section{RESULTS}

In the 66 Polish sub-regions studied, the mean percentage of LBW for 2005-2014 was 5.85 and ranged from 4.34 in the Białostocki sub-region to 8.83 in Łódź (Tab. 1). Significant temporal changes in the LBW incidence rate were observed in the mentioned period in Poland AAPC $_{2005-2014}=-0.44 \%$, 95\% CI: $-0.67 \%,-0.20 \%)$. However, the dynamics of LBW incidence rate varied by sub-region: in the majority of subregions, and the LBW decreased during the study period. Whereas in 46 sub-regions the change assumed a negative value of $-3.60 \% /$ year (Ciechanowsko-Płocki) to $-0.05 \% /$ year (Bydgosko-Toruński). In the remaining 20 sub-regions, an increase was observed ( +0.32 /year to $+2.21 /$ year), changes above $+1 \%$ /annually occurred in urban sub-regions or surrounding large cities, i.e. Łódzki - 1.05\%, Opolski $1.12 \%$, Krakowski - 1.17\%, Poznański - 1.21\%, Rzeszowski - 1.23\%, Szczecinski - 1.63\%, Bielski - 1.84\%, Tyski - 1.87\%, Warszawa $-1.82 \%$, Kraków $-1.95 \%$, and Wrocław $-2.21 \%$ (Fig. 1). Descriptive statistics for SES in the 66 Polish subregions in the study period are presented in Table 1.

A positive correlation was found between mean incidence rate of LBW (average for 2005-2014) and unemployment ( $\mathrm{r}=$ $0.29 ; \mathrm{p}=0.018$ ), and negative correlation with housing area $(\mathrm{r}=-0.26 ; \mathrm{p}=0.038)$, while the relationships with GERTEL, average salary, GDP and density of population were not statistically significant (Tab. 2). 


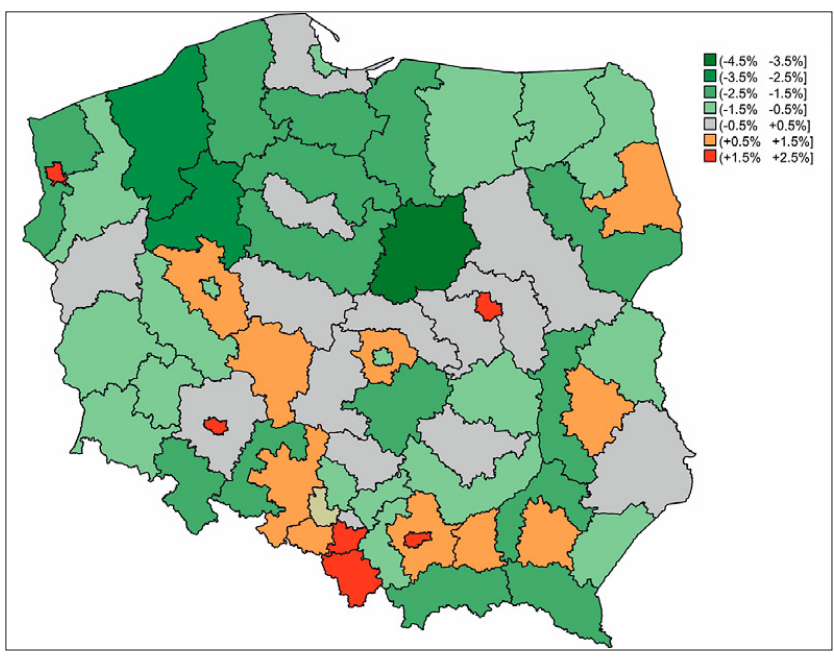

Figure 1. Average annual percentage changes in incidence rate of low birth weight below 2,500 g in 66 sub-regions of Poland in 2005-2014

Table 1. Descriptive statistics for 66 ub-regions of Poland weighted for number of live births in 2005-2014

\begin{tabular}{|c|c|c|c|c|}
\hline Variable name [unit] & $\bar{x}(\mathrm{SD})$ & $\mathrm{Me}$ & Q1-Q3 & Range \\
\hline $\begin{array}{l}\text { Low birth weight < } \\
2,500 \mathrm{~g}[\% \text { live births }]\end{array}$ & $5.85(0.72)$ & 5.75 & $5.36-6.22$ & $4.34-8.83$ \\
\hline $\begin{array}{l}\text { Gross Enrollment Rate } \\
\text { at tertiary education } \\
\text { level [\%] }\end{array}$ & $4.51(6.13)$ & 1.54 & $0.61-6.12$ & $0.01-25.37$ \\
\hline Average salary [PLN] & $3053(678)$ & 2999 & $2576-3408$ & $1864-5386$ \\
\hline $\begin{array}{l}\text { Gross Domestic } \\
\text { Product per capita } \\
{[\mathrm{PLN}]}\end{array}$ & 36188 (19793) & 30152 & 24749-39144 & 15529-131026 \\
\hline Unemployment rate [\%] & $13.29(5.66)$ & 13.30 & $9.37-16.8$ & $1.80-33.20$ \\
\hline $\begin{array}{l}\text { Housing area } \\
\text { per inhabitant }\left[\mathrm{m}^{2}\right]\end{array}$ & $24.92(2.29)$ & 24.60 & $23.30-26.20$ & $20.30-33.60$ \\
\hline $\begin{array}{l}\text { Density of population } \\
\text { [person } / \mathrm{km}^{2} \text { ] }\end{array}$ & $505(880)$ & 124 & $86-265$ & 44-3309 \\
\hline
\end{tabular}

Symbols: $\bar{x}$ - mean value; SD - standard deviation; Q1 - $1^{\text {st }}$ quartile; Me - median; Q3 - $3^{\text {rd }}$ quartile

Table 2. Spearman correlation coefficients of study variables and incidence rate of low birth weight below 2,500 g in 66 sub-regions of Poland in 2005-2014

\begin{tabular}{lcc}
\hline Variable & $r$ & $p$ \\
\hline GERTEL & 0.09 & 0.456 \\
\hline Average salary & -0.02 & 0.883 \\
\hline GDP & 0.01 & 0.924 \\
\hline Unemployment & 0.29 & 0.018 \\
\hline Housing area & -0.26 & 0.038 \\
\hline Density of population & 0.10 & 0.428 \\
\hline
\end{tabular}

GERTEL - Gross Enrollment Rate at the Tertiary Education Level GDP - Gross Domestic Product

A significant relationship was detected between LBW and the socio-economic features (Tab. 3). In model 1, a significant increase in unemployment by $1.0 \%$ was associated with an increase of LBW by $0.5 \%$. Increase of average salary by 100 PLN was associated with a decrease of LBW by $1.3 \%$, increase of GERTEL by $1.0 \%$ was associated with a decrease of LBW by $1.0 \%$, increase of housing area by $1.0 \mathrm{~m}^{2}$ was associated with a decrease of LBW by $0.9 \%$. Model 2 disclosed a significant unfavourable association between a two-fold increase in density of population with an increase of LBW by $6.8 \%$, and a still existing significant association between increase of unemployment by $1.0 \%$ and an increase of LBW by $0.4 \%$, an increase in average salary by 100 PLN was associated with a decrease of LBW by $1.0 \%$, and increase of GERTEL by $1.0 \%$ was associated with a decrease of LBW by $0.9 \%$. In models 1 and 2, minor dependencies were observed between LBW with GDP which, however, were statistically insignificant; in model 2, the relationship with housing area disappeared.

Analysis of the QICC index in models with a single socio-economic variable adjusted for density of population showed that among all the analyzed SES variables, the occurrence of LBW best explains the differences in the level of unemployment. Obviously, in a multivariable model that takes into account all SES variables, the explanation of differences in the occurrence of LBW between sub-regions is more accurate (Tab. 3).

Table 3. Model of associations between socio-economic status and incidence rate of low birth weight below 2,500 g in 66 sub-regions of Poland in 2005-2014

\begin{tabular}{|c|c|c|c|c|}
\hline \multirow{2}{*}{$\begin{array}{l}\text { Variable } \\
\text { [unitary } \\
\text { change of } \\
\text { independent } \\
\text { variable] }\end{array}$} & \multicolumn{2}{|l|}{ Model $1 \dagger$} & \multicolumn{2}{|l|}{ Model 2†† } \\
\hline & $\operatorname{IRR}(95 \% \mathrm{Cl})$ & QICC & $\operatorname{IRR}(95 \% \mathrm{CI})$ & QICC \\
\hline $\begin{array}{l}\text { GERTEL } \\
\text { [per 1\%] }\end{array}$ & $0.990^{* *}(0.984,0.997)$ & 3162.5 & $0.991 * *(0.985,0.997)$ & \\
\hline $\begin{array}{l}\text { Average salary } \\
\text { [per } 100 \text { PLN] }\end{array}$ & $0.987^{* * *}(0.981,0.993)$ & 3231.6 & $0.990^{* * *}(0.984,0.996)$ & \\
\hline $\begin{array}{l}\text { GDP } \\
\text { [per } 1000 \text { PLN] }\end{array}$ & $0.998(0.997,1.000)$ & 3053.6 & $1.000(0.999,1.002)$ & \\
\hline $\begin{array}{l}\text { Unemployment } \\
\text { [per 1\%] }\end{array}$ & $1.005^{* * *}(1.003,1.006)$ & 2900.7 & $1.004^{* * *}(1.002,1.005)$ & 2748.6 \\
\hline $\begin{array}{l}\text { Housing area } \\
{\left[\text { per } \mathrm{m}^{2}\right]}\end{array}$ & $0.991 *(0.982,0.999)$ & 3086.6 & $0.992(0.982,1.002)$ & \\
\hline $\begin{array}{l}\text { Density of } \\
\text { population } \\
\text { [per two-fold } \\
\text { increase] }\end{array}$ & NA & NA & $1.068^{* * *}(1.038,1.098)$ & \\
\hline
\end{tabular}

${ }^{\dagger}$ model with single socio - economic variable adjusted for density of population ${ }^{\mathrm{tt}}$ multivariable model

IRR - Incidence Rate Ratio
IRnariable model

IRR - Incidence Rate Ratio
QICC - Corrected Quasi-Likelihood under Independence Model Criterion

GERTEL - Gross Enrollment Rate at the Tertiary Education Level

GDP - Gross Domestic Product

NA - not applicable

${ }^{* * *} p \leq 0.001 ;{ }^{* *} p \leq 0.01 ;{ }^{*} p \leq 0.05$

\section{DISCUSSION}

Main findings. All incidence of live births with LBW ( $\mathrm{n}=$ 227,696) in Poland in the years 2005-2014 were analyzed to assess whether SES and urbanization at sub-regions level were associated with LBW. The analysis confirmed important regional disparities in the health of newborns in the Polish population, and contributed to the identification of socio-economic characteristics associated with favourable or adverse birth outcomes. In most sub-regions, a decrease in LBW incidence rate was observed; however, an upward trend in LBW occurred in big cities and in the sub-regions surrounding large cities. A lower incidence rate of LBW was detected among mothers living in the sub-regions with the highest level of SES. Protective factors for the health of newborns were a higher level of education and income 
for the mothers. An unfavourable association was detected between worse birth outcomes in sub-regions with high unemployment. Moreover, the multivariable model disclosed an association between adverse birth outcomes and higher density of population. The obtained results were consistent also with the results of some studies from outside of Poland on the relationship between LBW and level of education [24], economic condition [25], unemployment [26] and urbanization [27]. According to the study performed by Meng et al., approximately $20-30 \%$ of factors that influence the birth outcomes are related to neighbourhood-level SES variables. The remaining $70-80 \%$ are connected with mothers' health status and behaviours [10].

Limitation and strengths. Interpretation of the analysis showed some limitations, the most important of which were a consequences of the chosen research method - an ecological study. First, relations that exist at the population level do not necessarily reflect those on the level of the individual (ecological fallacy). Further, an ecological study does not allow the control of confounding factors. Also, although the presented findings are in accordance with the results of other studies, no conclusion on casual relationships could be postulated [28].

Another limitation of the analysis was the number of variables resulting from the national system for registering births, which does not contain information on the mother's diseases, health care and occupation. There is also no information about tobacco consumption during pregnancy as an important LBW risk factor [29], which may overestimate the impact of socio-economic variables. An additional important limitation is the lack of classification of available data on socio-economic status (education, income, GDP, unemployment, housing area), divided into urban and rural areas in the sub-regions. Therefore, to overcome this limitation, the density of population as a variable describing the degree of urbanization was used.

As far as the authors of this study are aware, this is the first such study in Poland to measure features of the socioeconomic and urbanization with LBW. Complete data on live births, based on information from birth cards in the ten-year period 2005 to 2014, were used in the study, the advantage of which was the use of national data based on the NUTS-3 classification, enabling an analysis with high statistical power. The use of quantitative measurement as part of an ecological correlation study based on routine reporting, made it possible to provide information about social inequalities in health of newborns when information at an individual level was not available. As other studies suggest [30], reducing the risk at the level of individual pregnancies is not enough to prevent or reduce adverse birth outcomes. This approach highlights the role of analyzes at the population level, taking into account structural factors [10, 31, 32].

The strength of the research is the map (Fig. 1) showing that despite the decline in the incidence rate of LBW in the majority of sub-regions of Poland, the situation in the subregions with high population density deteriorated. This result can be used to plan appropriate prevention programmes at the local level, aimed at benefiting newborns as well as building health capital for future generations.

Comparison with other studies. The study shows that the increase in population density was strongly associated with the increase in LBW. Many studies indicate that an important role in explaining the risk of LBW may be played by place of residence, which is a heterogeneous category of rural-urban continuum $[33,34]$. Urbanization is associated with a place of residence that may have substantial influence on access to health care, and have an impact on health in terms of environmental exposure. In the urban environment there is a large amount of overcrowding, transport system and noise that pose a significant risk to the health condition of pregnant women $[35,36]$. There is evidence that pregnant urban women who smoked tobacco and consumed alcohol more frequently, were affected more acutely by job-related stress, compared to pregnant rural women $[37,38]$. However, there are also other factors related to rural environment which may be protective for birth outcomes. The results of studies carried out in a Spanish population [39] showed that in areas with a large accumulation of green surroundings, newborns were characterized by higher values of birth parameters (weight and head circumference). It is also possible that lower exposure to air pollution, which characterize rural regions, may also play a role [34]. The more favourable influence of rural areas on the health of newborns may result from a stronger impact of health behaviours, occupation and environmental conditions, despite the fact that the level of socio- economic development in rural areas is weaker compared to cities.

In addition to the result showing the relationship between increase in population density and increase in LBW, attention should be paid to the existence of growing LBW trends in the sub-regions surrounding large cities. These results may indicate significant changes in the living conditions of women of childbearing age depending on their place of residence. Surveys conducted in households in Poland show a gradual improvement in living conditions, both in cities and in rural areas, with a significant reduction in the distance between material living conditions in rural areas and more urbanized areas. In the decade 2005-2015, the dynamics of beneficial changes were faster in rural areas, e.g. the disposable income per one person in a household in the rural areas increased by $87 \%$, and in urban areas by $81 \%$. In the countryside, the furnishing of apartments with sanitary and technical installations has also improved significantly, and the household area has also increased [40]. Previous research by the authors of the current study on mortality patterns below the first year of life, involved the increase of mortality in rural areas in comparison to urban areas [41]. A possible reason is the inflow of urban population aged 25-44 to rural areas located around large cities, associated with the transfer of urban lifestyle.

In the current study, an increase was also observed in adverse birth outcomes in four metropolitan sub-regions, which might be partially associated with an increase in socio- economic inequalities among women of childbearing age. However, based on the current study, it was not possible to assess this relationship. To assess the etiology of the trends determined in this analysis, further research will be needed to consider the differing effects of other factors operating over time.

In addition to the adverse impact of urbanization, the results of the current study also show that better birth outcomes occur in societies with higher levels of education, income, and less unemployment. The protective influence of the mother's higher education on the health of newborns 
has been confirmed by the results of other studies [24]. The level of education among women of childbearing age and pregnant women influences the employment status, as well as greater knowledge about beneficial health behaviours affecting the birth weight (folic acid supplementation, appropriate antenatal care). It should be noted that education can be important not only at the individual level, but also at the level of the community through the transfer of health attitudes [42]. Another factor strongly associated with the results of birth outcomes is a high level of income, which determines access to food, better standard of housing, health care and prevention. As the research results show [10,26], women living in less developed areas characterized by high unemployment are burdened with deprivation leading to chronic stress, which may affect development of the foetus.

The presented results show that decrease in the LBW incidence rate of $-0.44 \%$ per year, observed between $2005-$ 2014, is not as dynamic as that noted between 1993-2000, when it reached the value of $-4.25 \%$ per year. This favourable outcome was achieved by the introduction and action of preventive programmes directed towards childbearing and pregnant women [43]. Unfortunately, after 2000, such programmes were discontinued. Therefore, the construction of population strategies are recommended, directed towards improvement of the education level and economic conditions of women living in high-density areas. Failure to take preventive action in the mentioned group of women might result in an increase in the LBW incidence rate observed today in many developed countries.

\section{CONCLUSIONS}

The study findings suggest that at the population level the incidence rate of LBW was lower among mothers living in the sub-regions with the highest level of SES. Protective factors for the health of newborns were a higher level of education and income. An unfavourable association was detected between LBW and high population density. The obtained results show that the place of residence should be taken into account when planning interventions to improve the situation of women of childbearing age and pregnant women. The study on health gaps should remain a priority in research to identify factors negatively affecting the health of newborns in all types of communities.

\section{Acknowledgements}

This study was funded by the Medical University of Bialystok, Poland (Decision No. N/ST/ZB/17/002/3303).

\section{REFERENCES}

1. UNICEF: Innocenti Report Card 11: Warunki i jakość życia dzieci w krajach rozwiniętych - analiza porównawcza. UNICEF, Florencja 2013.

2. World Health Organization, UNICEF: Low birthweight: country, regional and global estimates. Geneva, WHO 2004.

3. Marmot M. Review of social determinants and the health divide in the WHO European Region: final report. WHO, Copenhagen 2013.

4. Goldenberg R, Culhane J. Low birth weight in the United States. Am J Clin Nutr. 2007; 85(Suppl): 584S-590S.

5. EURO-PERISTAT: European Perinatal Health Report. The health and care of pregnant women and babies in Europe in 2010. http://www. europeristat.com/images/doc/Peristat\%202013\%20V2.pdf (access: 2018.01.09)
6. Barker DJ. Adult consequences of fetal growth restriction. Clin Obstet Gynecol. 2006; 49(2): 270-283.

7. Johnson C, Jones S, Paranjothy S. Reducing low birth weight: prioritizing action to address modifiable risk factors. J Public Health (Oxf). 2017; 39(1): $122-131$.

8. Schempf A, Strobino D, O'Campo P. Neighborhood effects on birth weight: an exploration of psychosocial and behavioral pathways in Baltimore, 1995-1996. Soc Sci Med. 2009; 68(1): 100-110.

9. Jarosińska D, Polańska K, Wojtyniak B, Hanke W. Towards estimating the burden of disease attributable to second-hand smoke exposure in Polish children. J Occup Med Environ Health. 2014; 27(1): 38-49.

10. Meng G, Thompson M, Brent Hall G. Pathways of neighbourhood-level socio-economic determinants of adverse birth outcomes. Int J Health Geogr. 2013; 12: 32. doi: 10.1186/1476-072X-12-32.

11. Casas M, Cordier S, Martínez D, Barros H, Bonde JP, Burdorf A, et al. Maternal occupation during pregnancy, birth weight, and length of gestation: combined analysis of 13 European birth cohorts. Scand J Work Environ Health. 2015; 41(4): 384-396.

12. Erickson A, Ostry A, Chan L, Arbour L. The reduction of birth weight by fine particulate matter and its modification by maternal and neighbourhood-level factors: a multilevel analysis in British Columbia, Canada. Environ Health. 2016; 15: 51. doi: 10.1186/s12940016-0133-0.

13. World Health Organization: European Health Information Gateway. https://gateway.euro.who.int/en/hfa-explorer/ (access: 2018.01.19).

14. EUROSTAT: Statistical books. Key figures on Europe 2015 edition. Eurostat, Luxembourg 2015.

15. Janiszewska R. Wiek matek i kolejność porodów a cechy somatyczne noworodków. Hyg Publ Health. 2011; 46(2): 261-265.

16. Brzozowska M, Kowalska-Koprek U, Kuś E, Berner-Trąbska M, Karowicz-Bilińska A. Analiza wskazań do porodu drogą cięcia cesarskiego noworodków ze skrajnie niską masą urodzeniową (<1500g) urodzonych w latach 2006-2010 w I Katedrze Ginekologii i Położnictwa UM w Łodzi. Ginekol Pol. 2011; 82(8): 592-597.

17. Jakiel G, Wilińska M, Bińkowska M, Kowal A, Rumowska S, Ciebiera M. Late preterm infants - impact of perinatal factors on neonatal results. A clinical study. Ann Agric Environ Med. 2015; 22(3): 536-541.

18. Borkowski W, Mielniczuk H. Społeczne i zdrowotne uwarunkowania zespołu zaburzeń oddychania u noworodków przedwcześnie urodzonych. Ginekol Pol. 2007; 78(1): 856-860.

19. Wójtowicz E, Duda-Biernacka B. Czynniki ryzyka wystąpienia niskiej urodzeniowej masy ciała (LBW) dziecka - regresja logistyczna. Med Og Nauk Zdr. 2015; 21(3): 244-249.

20. Piekarska E, Krasomski G, Dominowska J, Tobor E. Ocena wpływu wybranych czynników socjalno-demograficznych na przedwczesne zakończenie ciąży i urodzeniową masę ciała noworodków. Perinatol Neonatol Ginekol. 2010; 3(4): 277-281.

21. Waszak M, Cieślik K, Lewandowski J, Boch-Kmieciak J, Szulc P, Bręborowicz G. Porównanie biometrycznych parametrów noworodków z ciąży bliźniaczej pochodzących ze środowiska wiejskiego i miejskiego w Wielkopolsce. Ginekol Pol. 2016; 87(2): 124-130.

22. European Commission: Regions in the European Union. Nomenclature of territorial units for statistics. NUTS 2006/EU-27. http://ec.europa. eu/eurostat/web/products-manuals-and-guidelines/-/KS-RA-07-020 (access: 2018.02.21)

23. Zeger S, Liang K. Longitudinal data analysis for discrete and continuous outcomes. Biometrics. 1986; 42(1): 121-130.

24. Pei L, Kang Y, Zhao Y, Cheng Y, Yan H. Changes in socioeconomic inequality of low birth weight and macrosomia in Shaanxi province of Northwest China, 2010-2013. A cross-sectional study. Medicine (Baltimore). 2016; 95(5): e2471. doi: 10.1097/MD.0000000000002471.

25. Nkansah-Amankra S, Dhawain A, Hussey J, Luchok K. Maternal social support and neighborhood income inequality as predictors of low birth weight and preterm birth outcome disparities: analysis of South Carolina pregnancy risk assessment and monitoring system survey, 2000-2003. Matern Child Health J. 2010; 14(5): 774-785.

26. Räisänen S, Kramer M, Gissler M, Saari J, Heinonen S. Unemployment at municipality level is associated with an increased risk of small for gestational age births - a multilevel analysis of all singleton births during 2005-2010 in Finland. Int J Equity Health. 2014; 13: 95. doi: 10.1186/s12939-014-0095-1.

27. Garcia-Subirats I, Pérez G, Rodríguez-Sanz M, Ruiz-Muñoz D, Salvador J. Neighborhood inequalities in adverse pregnancy outcomes in an urban setting in Spain: a multilevel approach. J Urban Health. 2012; 89(3): 447-463.

28. Beaglehole R, Bonita R, Kjellstrom T. Basic epidemiology. WHO, Geneva 1993. 
29. van den Berg G, van Eijsden M, Vrijkotte TG, Gemke RJ. Educational inequalities in perinatal outcomes: the mediating effect of smoking and environmental tobacco exposure. PLoS One. 2012; 7(5): e37002. doi: 10.1371/journal.pone.0037002.

30. Witt W, Park H, Wisk L, Cheng E, Mandel K, Chatterjee D. Neighborhood disadvantage, preconception stressful life events, and infant birth weight. Am J Public Health. 2015; 105(5): 1044-1052.

31. English P, Kharrazi M, Davies S, Scalf R, Waller L, Neutra R. Changes in the spatial pattern of low birth weight in a southern California county: the role of individual and neighborhood level factors. Soc Sci Med. 2003; 56(10): 2073-2088.

32. Morenoff J. Neighborhood mechanisms and the spatial dynamics of birth weight. AJS. 2003; 108(5): 976-1017.

33. Hillemeier M, Weisman C, Chase G, Dyer A. Individual and community predictors of preterm birth and low birthweight along the rural - urban continuum an central Pennsylvania. J Rural Health. 2007; 23(1): 42-48.

34. Kent S, McClure L, Zaitchik B, Gohlke J. Area-level risk factors for adverse birth outcomes: trends in urban and rural settings. BMC Pregnancy Childbirth. 2013; 13: 129 doi: 10.1186/1471-2393-13-129.

35. Ompad D, Galea S, Caiaffa W, Vlahov D. Social determinants of the health of urban populations: methodologic considerations. J Urban Health. 2007; 84(Suppl 1): 42-53.

36. Nieuwenhuijsen M. Urban and transport planning, environmental exposures and health-new concepts, methods and tools to improve health in cities. Environ Health. 2016; 15(Suppl 1): 38. doi: 10.1186/ s12940-016-0108-1.

37. Żukiewicz-Sobczak W, Paprzycki P, Zwoliński J. Zachowania zdrowotne kobiet w ciąży. Instytut Medycyny Wsi, Lublin 2013.

38. Biernacka J, Hanke W, Makowiec-Dąbrowska T, Makowska Z, Sobala W. Psychospołeczne uciążliwości środowiska pracy zawodowej kobiet ciężarnych a ryzyko występowania porodu przedwczesnego. Med Pr. 2007; 58(3): 205-214.

39. Dadvand P, Sunyer J, Basagaña X, Ballester F, Lertxundi A, FernándezSomoano A, et al. Surrounding greenness and pregnancy outcomes in four Spanish birth cohorts. Environ Health Perspect. 2012; 120(10): 1481-1487.

40. Główny Urząd Statystyczny: Sytuacja społeczno-ekonomiczna gospodarstw domowych w latach 2000-2015. Zróżnicowanie miasto - wieś. GUS, Warszawa 2017.

41. Genowska A, Zalewska M, Jamiołkowski J, Stepaniak U, Szpak A, Maciorkowska E, et al. Inequalities in mortality of infants under one year of age according to foetal causes and maternal age in rural and urban areas in Poland, 2004-2013. Ann Agric Environ Med. 2016; 23(2): 285-291.

42. Diez Roux A, Mair C. Neighborhoods and health. Ann N Y Acad Sci. 2010; 1186: 125-145.

43. Program Narodów Zjednoczonych ds. Rozwoju: Zdrowie kobiet w wieku prokreacyjnym 15-49 lat. Polska 2006. UNDP, Warszawa 2007. 